\title{
Serum Ferritin and Metal Levels as Risk Factors for Amyotrophic Lateral Sclerosis
}

\author{
Muddasir Qureshi* ${ }^{, 1,2}$, Robert H. Brown Jr. ${ }^{2,3}$, Jack T. Rogers ${ }^{4}$, Merit E. Cudkowicz ${ }^{1,2}$ \\ ${ }^{I}$ Neurology Clinical Trials Unit; ${ }^{2}$ Department of Neurology; ${ }^{3}$ Day Neuromuscular Research Laboratory; ${ }^{4}$ Department of \\ Psychiatry-Neuroscience, Massachusetts General Hospital, Harvard Medical School, Charlestown, MA, 02129, USA
}

\begin{abstract}
Metal toxicity has been identified as a possible risk factor for amyotrophic lateral sclerosis (ALS) and other neurodegenerative disorders. We conducted a retrospective chart review of urinary, hair and blood metal levels and serum ferritin in 321 people with ALS seen over a ten-year period at the Massachusetts General Hospital (MGH). We found that hair lead levels and serum ferritin levels were elevated in ALS patients compared to published normal values. Metal levels of arsenic, lead, mercury, cadmium, thallium, cobalt and aluminum in 24-hour urine specimens and lead, mercury and arsenic in serum were within the normal range. We conclude that twenty-four hour urine or blood testing for metals is not warranted as part of the evaluation of ALS. Elevated levels of serum ferritin in ALS population could reflect an underlying perturbation in iron metabolism.
\end{abstract}

\section{INTRODUCTION}

Amyotrophic lateral sclerosis (ALS) is a fatal neurodegenerative disorder that affects predominantly motor neurons. The cause of the sporadic form of ALS is unknown [1, 2]; metal toxicity has been proposed as a possible risk factor [3, 4]. Several approaches have been taken to investigate metal toxicity in ALS, including: measuring metal levels in body tissues and fluids; comparing case-control cohorts to establish the risk of contracting ALS from metal exposure; and evaluating case reports of clinical syndromes resembling ALS that developed following metal exposure. The possibility that people with ALS might have a genetic susceptibility to the effects of metals has also been studied [5]. Serum ferritin levels reflect both inflammation and iron imbalance in defined pathophysiological conditions such as hemochromatosis (iron) and the anemia of chronic disease (inflammation) [6-8]. We conducted a retrospective analysis of measurements of metals in urine, blood and hair samples and tested serum ferritin levels in ALS compared to age matched subjects.

\section{METHODS}

A retrospective chart review of 321 people with ALS seen at the Neuromuscular Clinic at the Massachusetts General Hospital (MGH) between January 1994 and December 2003 was performed. Approval for the chart review was obtained from the MGH Institutional Review Board. Participants were selected if they were evaluated for at least one laboratory test related to metal level in serum, hair or urine. All participants were identified using the computerized MGH Research Patient Data Registry (RPDR) and each participant's diagnosis was confirmed according to the ElEscorial criteria [9]. Participant's gender, date of birth, site and date of symptom onset and date of diagnosis were

*Address correspondence to this author at the Massachusetts General Hospital, Building $149,13^{\text {th }}$ Street, Room 2274, Charlestown, MA 02129, USA; Tel: 617-726-9095; E-mail: mqureshi@partners.org recorded. The participants were selected randomly based on availability of outpatient medical records. All patients whose complete medical record file was maintained at the Outpatient Clinic were included in the chart review. The laboratory samples collected from the patients were analyzed at the Nichols Institute in Chantilly, Virginia. Normal reference ranges for metals were available and had been obtained from published data and private internal testing of healthy volunteers at the Nichols Institute [10-12].

After the initial chart review, additional stored serum samples from 30 participants with ALS and 30 healthy control volunteers who participated in an ALS observational study from 1998 to 2002 [13] were analyzed for ferritin levels. These samples were sent to the Pathology Laboratory at MGH and analyzed using an electrochemiluminescent immunoassay, ELECSYS 2010 (Roche Diagnostics, Indianapolis, IN).

Statistical analyses were performed using SAS version 8.0 (Cary, NC), and a univariate analysis were used to analyze the data. Student's T-test was used to compare ferritin levels between ALS patients and controls.

\section{RESULTS}

The majority of participants were male (59\%) and the mean age at symptom onset was 56.3 years $( \pm 13.0 \mathrm{SD})$. The number of participants who underwent each laboratory test and the normal reference ranges are provided in Table $\mathbf{1}$. The mean 24-hour urine levels of arsenic, lead, mercury, cadmium, thallium, cobalt and aluminum were within the normal range (Table 1). Four participants had lead levels measured from hair. The average hair lead level was elevated (1.9 $\mathrm{ug} / \mathrm{gm} \pm 2.6 \mathrm{SD}$; normal range $=0-0.99 \mathrm{ug} / \mathrm{gm})$. Serum ferritin levels were measured in 12 participants (six male and six females). The mean serum ferritin level was elevated in the participants with ALS. In males with ALS, the average ferritin level was $668 \mathrm{ng} / \mathrm{ml}$ ( $\pm 785.1 \mathrm{SD})$ compared to a normal range of $22-322 \mathrm{ng} / \mathrm{ml}$. In female ALS patients, the 
Table 1. Metal Levels in Blood, Hair and 24-Hour Urine Samples

\begin{tabular}{|c|c|c|c|c|}
\hline Laboratory Investigation & Number of ALS Subjects & Mean Level--ALS Subjects (units) & Standard Deviation (SD) & Normal Range \\
\hline \multicolumn{5}{|l|}{ Urine } \\
\hline Lead & 110 & $13.7(\mathrm{mcg} / \mathrm{L})$ & 10.9 & $0-50 \mathrm{mcg} / \mathrm{L}$ \\
\hline Mercury & 112 & $8.9(\mathrm{mcg} / \mathrm{L})$ & 2.7 & $0-20 \mathrm{mcg} / \mathrm{L}$ \\
\hline Thallium & 79 & $0.9(\mathrm{mcg} / \mathrm{L})$ & 1.8 & $0-2 \mathrm{mcg} / \mathrm{L}$ \\
\hline Cobalt & 70 & $0.5(\mathrm{mcg} / \mathrm{L})$ & 0.1 & $0-2 \mathrm{mcg} / \mathrm{L}$ \\
\hline Aluminum & 8 & $12.9(\mathrm{mcg} / 24 \mathrm{hr})$ & 8.9 & $7-40 \mathrm{mcg} / 24 \mathrm{hr}$ \\
\hline \multicolumn{5}{|l|}{ Serum } \\
\hline Mercury & 6 & $15.2(\mathrm{ug} / \mathrm{L})$ & 6.4 & $0-50 \mathrm{ug} / \mathrm{L}$ \\
\hline \multicolumn{5}{|l|}{ Hair } \\
\hline Lead & 4 & $1.9(\mathrm{ug} / \mathrm{GM})$ & 2.6 & $0-0.99 \mathrm{ug} / \mathrm{GM}$ \\
\hline Arsenic & 5 & $0.2(\mathrm{ug} / \mathrm{GM})$ & 0.4 & $0-0.9 \mathrm{ug} / \mathrm{GM}$ \\
\hline Mercury & 5 & $1.7(\mathrm{ug} / \mathrm{GM})$ & 1.1 & $0-24.9 \mathrm{ug} / \mathrm{GM}$ \\
\hline \multicolumn{5}{|l|}{ Serum Ferritin } \\
\hline Male & 6 & $668.0(\mathrm{ng} / \mathrm{mL})$ & 785.1 & $22-322 \mathrm{ng} / \mathrm{mL}$ \\
\hline
\end{tabular}

average ferritin level was $237.2 \mathrm{ng} / \mathrm{ml}$ ( \pm 180.3 SD; normal range $10-291 \mathrm{ng} / \mathrm{ml}$ ).

Based on these results we conducted additional analysis of serum ferritin levels in 30 individuals with ALS and 30 healthy controls. Compared with the healthy controls, the mean serum ferritin level in the ALS population was higher (ANOVA: males $\mathrm{p}=0.037$, females $\mathrm{p}=0.032$ ). The mean serum ferritin level in the 17 males with ALS was $269.9 \mathrm{ng} / \mathrm{ml}$ ( \pm 126.4 SD), compared to $164.1 \mathrm{ng} / \mathrm{ml}( \pm 142.2 \mathrm{SD})$ in 14 healthy controls. The mean serum ferritin value in $13 \mathrm{fe}-$ males with ALS was $183.5 \mathrm{ng} / \mathrm{ml}$ ( $\pm 186.9 \mathrm{SD})$ compared to $71.3 \mathrm{ng} / \mathrm{ml}( \pm 60.4 \mathrm{SD})$ in 16 female control subjects (Figs. 1 and 2).

\section{DISCUSSION}

In a chart review of patients with ALS seen at MGH over a 10-year period we did not find evidence of increased metal levels in urine or blood compared to healthy controls. The hair lead levels were elevated in a limited number of participants who had this test performed. We also found significantly increased serum ferritin levels in both males and females with ALS. We confirmed this finding by measuring ferritin assays in a small set of stored serum samples.

Metal concentrations in blood and urine reflect recent exposures [14]; therefore measurements of metal levels in these tissues may not be useful except in clinical situations where a differential diagnosis between acute metal poisoning and a motor neuron disease is needed. The half-life of most metals in blood is usually measured in weeks [15]. By contrast, analysis of the metal content of hair is useful in assessing variations in long-term exposure to metals [16], especially vanadium [17], arsenic [18] and mercury [19]. How-

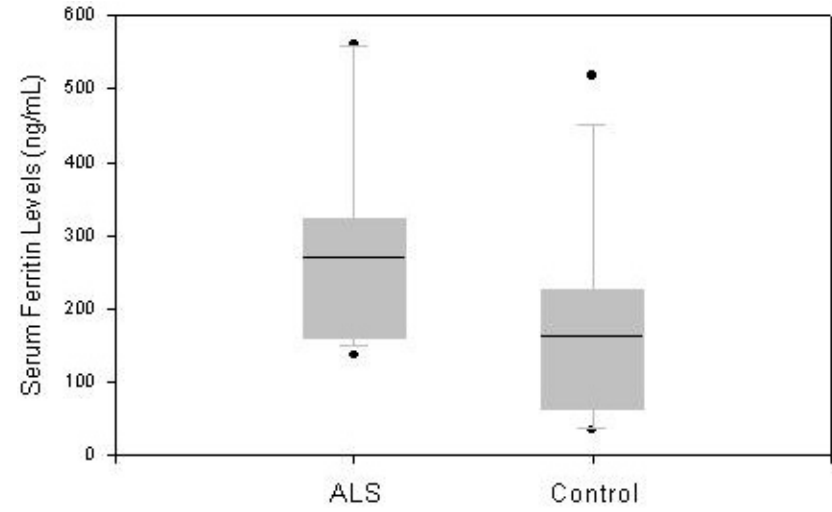

Fig. (1). The mean serum ferritin level in 17 male participants with ALS $(269.9 \mathrm{ng} / \mathrm{ml} \pm 126.4 \mathrm{SD})$ and 14 healthy controls (164.1 $\mathrm{ng} / \mathrm{ml} \pm 142.2 \mathrm{SD})$ is depicted in boxplot. The horizontal line reflects the median and the box provides the interquartile range from the $25^{\text {th }}$ to $75^{\text {th }}$ percentile. Dots represent the observations outside of 10th and 90th percentiles. 


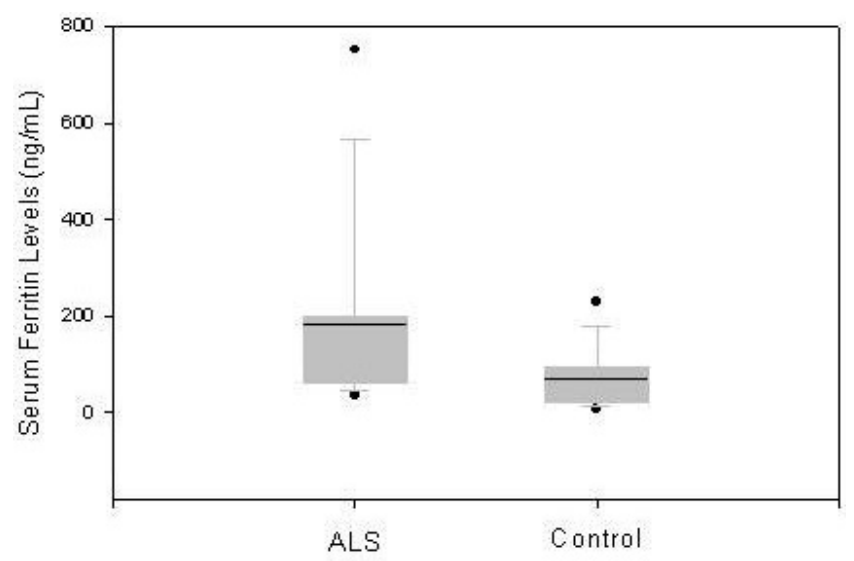

Fig. (2). The mean serum ferritin level in 13 female participants with ALS (183.5 ng/ml $\pm 186.93 \mathrm{SD})$ and 16 female controls (71.3 $\mathrm{ng} / \mathrm{ml} \pm 60.37 \mathrm{SD}$ ) is depicted in boxplot. The horizontal line reflects the median and the box provides the interquartile range from the $25^{\text {th }}$ to $75^{\text {th }}$ percentile. Dots represent the observations outside of 10 th and 90 th percentiles.

ever, several factors influence metal levels found in hair [20], and there is strong evidence of disparities between laboratories in hair metal measurements that cannot be attributed to the quality of laboratory methods [21, 22]. A recent study of hair metal levels in an ALS population found lower vanadium and manganese levels [17] but concluded that hair samples do not reflect exposures that may have occurred prior to the period in which the hair was growing. Chronic metal exposure can also be measured in bone. Since metals like lead and aluminum accumulate in the bones over the course of a lifetime, bone may be an endogenous source of these metals in the body [23]. The half-life of lead in the patella is three to five months, but in the tibia it is 15 to 25 years $[15,24]$. Direct measurement of lead levels in bone provides data on cumulative past exposure that can be used in epidemiological analysis and clinical assessment [25].

The finding that hair lead levels were elevated in our cohort supports the earlier published data that demonstrated chronic elevation of bone lead in patients with ALS [24]. It has been shown that metals like zinc and cadmium regulate translation of ferritin by modulating binding of Ironregulatory protein 1 (IRP1) to the Iron-regulatory element (IRE) in the 5'UTR of the ferritin mRNA [26]. It is possible that lead acts in a similar pathway to impact the synthesis of ferritin.

Elevated serum ferritin is an indicator of hemachromatosis and inflammatory stress [27]. The increased serum ferritin levels, as seen during inflammation [28], are induced by stress-induced factors such as interleukin-1 (IL-1) [29, 30]. Ferritin binds to iron and is involved in detoxifying iron and other trivalent trace metals in the brain [31]. In a transgenic mutation superoxide dismutase (SOD1) mouse model of motor neuron disease, neural ferritin expression was increased as a response to increased oxidative stress [32]. Defects in ferritin metabolism are possibly involved in etiology of other neurodegenerative deficits, including Friedrich ataxia [33], Parkinson's disease [34], and Alzheimer disease [35]. Despite several reports of altered iron metabolism [36] and increased total brain ferritin in individuals with $\mathrm{Alz}$ heimer disease [37], their serum ferritin levels remain within the normal range [38].

Another crucial question concerns the potential role in ALS of polymorphisms in the hemachromatosis gene (HFE), located on the short arm of chromosome 6 at location $6 \mathrm{p} 21.3$ [39]. Two mutations in the HFE gene, H63D and C282Y, have been reported to increase susceptibility to ALS [40-42]. The HFE protein affects iron metabolism by binding to the transferrin receptor and reducing its affinity for iron-binding transferrin. However, the HFE allele can independently increase neuronal oxidative stress levels without necessarily affecting iron load [39]. The altered activity of SOD1 (either wild-type or the mutant SOD1G93A) modulates the levels of ferritin as well as transferrin receptor [43]. In light of these findings it will be important to further study the role of ferritin in in vitro and in vivo models of SOD1 toxicity.

The finding of elevated serum ferritin in a large sample of ALS population may simply be an acute phase reactant, rather than a specific maker of iron metabolism dysregulation. The role of ferritin in ALS needs to be studied in a longitudinal cohort and its relationship with survival and measures of disease progression should be explored. We conclude that further study of the role of ferritin and other proteins involved in iron metabolism is warranted in the ALS population, particularly in relation to genetic polymorphisms that affect cellular oxidative stress levels.

\section{ACKNOWLEDGEMENTS}

MEC receives support from the Digiovanni Fund. RHB receives support from the Angel Fund, ALS Therapy Alliance, Project ALS, the Al-Athel ALS Research Foundation, the Pierre L. de Bourgknecht ALS Research Foundation and the NINDS (5R01NS050557-02 and 5R01NS05050641-04). JTR receives support from the National Institute of Aging.

\section{REFERENCES}

[1] Armon C, Kurland L, Daube J, O'brien P. Epidemiologic correlates of sporadic amyotrophic lateral sclerosis. Neurology 1991; 41(7): 1077-84.

[2] Brooks B. Clinical epidemiology of amyotrophic lateral sclerosis. Neurol Clin 1996; 14(2): 399-420.

[3] Kasarskis EJ, Ehmann WD, Markesbery WR. Trace metals in human neurodegenerative diseases. Prog Clin Biol Res 1993; 380: 299.

[4] Mitchell J. Heavy metals and trace elements in amyotrophic lateral sclerosis. Neurol Clin 1987; 5(1): 43-60.

[5] Kamel F, Umbach D, Lehman T, et al. Amyotrophic lateral sclerosis, lead, and genetic susceptibility: polymorphisms in the deltaaminolevulinic acid dehydratase and vitamin D receptor genes. Environ Health Perspect 2003; 111(10): 1335-9.

[6] Lipschitz DA, Cook JD, Finch CA. A clinical evaluation of serum ferritin as an index of iron stores. N Engl J Med 1974; 290(22): 1213-6.

[7] Koziol JA, Ho NJ, Felitti VJ, Beutler E. Reference centiles for serum ferritin and percentage of transferrin saturation, with application to mutations of the HFE gene. Clin Chem 2001; 47(10): 1804-10.

[8] Torti FM, Torti SV. Regulation of ferritin genes and protein. Blood 2002; 99(10): 3505-16.

[9] Brooks B. El Escorial World Federation of Neurology criteria for the diagnosis of amyotrophic lateral sclerosis. Subcommittee on motor neuron diseases/amyotrophic lateral sclerosis of the World Federation of Neurology Research Group on neuromuscular diseases and the El Escorial "Clinical limits of amyotrophic lateral sclerosis". J Neurol Sci 1994; 124: 96-107. 
[10] Dillon H, Ho M. Biological Monitoring of Exposure to Chemicals: Metals. $1^{\text {st }}$ ed: Wiley-Interscience 1991.

[11] Padgett RA, Grabowski PJ, Konarska MM, Seiler S, Sharp PA. Splicing of messenger RNA precursors. Ann Rev Biochem 1986; 55: $1119-50$

[12] CDC. Second National Report on Human Exposure to Environmental Chemicals. Atlanta: National Center for Environmental Health 2003

[13] Qureshi M, Hayden D, Urbinelli L, et al. Analysis of factors that modify susceptibility and rate of progression in amyotrophic lateral sclerosis (ALS). Amyotroph Lateral Scler 2006; 7(3): 173-82.

[14] Rabinowitz MB, Wetherill GW, Kopple JD. Lead metabolism in the normal human: stable isotope studies. Science 1973; 182(113): 725-7.

[15] Rabinowitz MB, Wetherill GW, Kopple JD. Kinetic analysis of lead metabolism in healthy humans. J Clin Invest 1976; 58(2): 26070.

[16] Klevay LM, Bistrian BR, Fleming CR, Neumann CG. Hair analysis in clinical and experimental medicine. Am J Clin Nutr 1987; 46(2): 233-6.

[17] Royce-Nagel G, Cudkowicz M, Myers D, et al. Determination of vanadium in patients with amyotrophic lateral sclerosis (ALS). Amyotroph Lateral Scler 2007; (Suppl 1): 211.

[18] Koons RD, Peters CA. Axial distribution of arsenic in individual human hairs by solid sampling graphite furnace AAS. J Anal Toxicol 1994; 18(1): 36-40.

[19] Cortes Toro E, De Goeij J, Bacso J, et al. The significance of hair mineral analysis as a means for assessing internal body burdens of envrionmental pollutants: results from an IAEA co-ordinated research programme. J Radioanalyt Nuclear Chem 1993; 167(2): 413-21.

[20] Sukumar A. Factors influencing levels of trace elements in human hair. Rev Environ Contam Toxicol 2002; 175: 47-78.

[21] Steindel SJ, Howanitz PJ. The uncertainty of hair analysis for trace metals. [comment]. JAMA 2001; 285(1): 83-5.

[22] Seidel S, Kreutzer R, Smith D, McNeel S, Gilliss D. Assessment of commercial laboratories performing hair mineral analysis.[see comment]. JAMA 2001; 285(1): 67-72.

[23] $\mathrm{Hu} \mathrm{H}$. Bone lead as a new biologic marker of lead dose: recent findings and implications for public health. Environ Health Perspect 1998; 106 (Suppl 4): 961-7.

[24] Kamel F, Umbach D, Munsat T, Shefner J, Hu H, Sandler D. Lead exposure and amyotrophic lateral sclerosis. Epidemiology 2002; 13: 311-9.

[25] Lilienfeld D, Ehland J, Landrigan P, et al. Rising mortality from motoneuron disease in the USA: 1962-84. Lancet 1989: 1(8640): 710-3.

[26] Martelli A, Moulis J-M. Zinc and cadmium specifically interfere with RNA-binding activity of human iron regulatory protein 1 . J Inorg Biochem 2004; 98(8): 1413-20.
[27] Brailsford S, Lunec J, Winyard P, Blake D. A possible role for ferritin during inflammation. Free Radic Res Commun 1985; 1(2): 101-9.

[28] Konijn AM, Carmel N, Levy R, Hershko C. Ferritin synthesis in Inflammation. II. Mechanism of Increased Ferritin Synthesis. Br J Haematol 1981; 49: 361-70.

[29] Rogers JT. Ferritin translation by interleukin-1: the role of sequences upstream of the start codons of the heavy and light subunit genes. Blood 1996; 87(6): 2525-37.

[30] Thomson AM, Cahill CM, Cho H-H, et al. The acute box cisElement in human heavy ferritin mRNA 5'-Untranslated region is a unique translation enhancer that binds Poly(C)-binding proteins. J Biol Chem 2005; 280(34): 30032-45.

[31] Fleming J, Joshi J. Ferritin: isolation of aluminum-ferritin complex from brain. Proc Natl Acad Sci USA 1987; 84(22): 7866-70.

[32] Olsen MK, Roberds SL, Ellerbrock BR, Fleck TJ, McKinley DK, Gurney ME. Disease mechanisms revealed by transcription profiling in SOD1-G93A transgenic mouse spinal cord. Ann Neurol 2001; 50(6): 730-40

[33] Gakh O, Park S, Liu G, et al. Mitochondrial iron detoxification is a primary function of frataxin that limits oxidative damage and preserves cell longevity. Hum Mol Genet 2006; 15(3): 467-79.

[34] Kaur H, Halliwell B. Evidence for nitric oxide-mediated oxidative damage in chronic inflammation. Nitrotyrosine in serum and synovial fluid from rheumatoid patients. FEBS lett 1994; 350(1): 9-12.

[35] Schubert D, Chevion M. The role of iron in beta amyloid toxicity. Biochem Biophys Res Commun 1995; 216(2): 702-7.

[36] Connor J, Lee S. HFE mutations and Alzheimer's disease. J Alzheimer's Dis 2006; 10(2-3): 267-76.

[37] Connor J, Snyder B, Beard J, Fine R, Mufson E. Regional distribution of iron and iron-regulatory proteins in the brain in aging and Alzheimer's disease. J Neurosci Res 1992; 31(2): 327-35.

[38] Fischer P, Gotz M, Danielczyk W, Gsell W, Riederer P. Blood transferrin and ferritin in Alzheimer's disease. Life Sci 1997; 60(25): 2273-8.

[39] Wang X, Lee S, Simmons Z, et al. Increased incidence of the Hfe mutation in amyotrophic lateral sclerosis and related cellular consequences. J Neurol Sci 2004; 227(1): 27-33.

[40] Goodall EF, Greenway MJ, van Marion I, Carroll CB, Hardiman O, Morrison KE. Association of the H63D polymorphism in the hemochromatosis gene with sporadic ALS. Neurology 2005; 65(6): 9347.

[41] Restagno G, Lombardo F, Ghiglione P, et al. HFE H63D polymorphism is increased in patients with amyotrophic lateral sclerosis of Italian origin. J Neurol Neurosurg Psychiatry 2007; 78(3): 327.

[42] Sutedja NA, Sinke RJ, Van Vught PWJ, et al. The association between H63D mutations in HFE and amyotrophic lateral sclerosis in a dutch population. Arch Neurol 2007; 64(1): 63-7.

[43] Danzeisen R, Achsel T, Bederke U, et al. Superoxide dismutase 1 modulates expression of transferrin receptor. J Biol Inorg Chem 2006; 11(4): 489-98.

Received: March 28, 2008

(C) Qureshi et al.; Licensee Bentham Open.

This is an open access article licensed under the terms of the Creative Commons Attribution Non-Commercial License (http://creativecommons.org/licenses/by-nc/3.0/) which permits unrestricted, non-commercial use, distribution and reproduction in any medium, provided the work is properly cited. 